\title{
The Role of Transportation Networks in enforcing the City Centrality: A Case Study of Budapest City
}

Ola Qasseer 1,*

1 ELTE Eötvös Loránd University, Institute of Geography and Earth Sciences, Department of Regional Sci-
ence, Budapest, Hungary; olaqasseer@student.elte.hu
* Correspondence: olaqasseer@student.elte.hu

With the increased importance of urban areas; cities have become the major centers of human activities. This has resulted in high levels of centrality in urban areas and has caused a rapidly increasing population. The development of transportation systems and the distribution of their networks affect this centrality by either enforcing or weakening it. Budapest city plays a major central role in Hungary. However, how does the distribution of transportation networks in Budapest affect its centrality? Does it influence the centrality level among various places in Budapest? This proposal attempts to find answers through measuring the centrality level according to the transportation network, by applying network analysis to determine the different levels of centrality in Budapest city. These measurements will help in understanding the role of transportation systems in the distribution of different activities inside the city, which will be important to develop transportation networks that offer more balance between different urban areas.

Keywords: City centrality; transportation systems; transportation networks; network analysis

\section{Theoretical background}

Citation: Qasseer, O.,2022, The Role of Transportation Networks in enforcing the City Centrality; A case study of Budapest City . SUPTM 2022 conference proceedings sciforum054261.

https://doi.org/10.31428/10317/10490 Publisher's Note: UPCT and Sciforum stays neutral with regard to jurisdictional claims in published maps and institutional affiliations.

Copyright: (c) 2022 by the authors. Submitted for possible open access publication under the terms and conditions of the Creative Commons Attribution (CC BY) license (https://creativecommons.org/license s/by/4.0/).

\subsection{The centrality of urban areas}

Urban areas could be described as a concentrated human settlement [1], aggregation with a specified number of inhabitants [2], centers with a specified population density [3], or agglomerated centers that provide job opportunities [4]. Cities are a complex component of human activities including commercial, touristic, and cultural events [5]. They have been affected by the industrial age and separated from agricultural work which led more working-class populations to concentrate and settle in these urban areas [6], and more numbers of urban residents [7], with more accessible possibilities for services and job opportunities that are supported by transportation systems [7]. The need for supplies in these new cities was encouraged by transportation networks. The development of these networks was very critical to the urbanization process [8]. Migration is a key factor in increasing urbanization $[8,9]$ In other words, the processes of concentration and the expansion of surrounding areas were a result of rural-urban migration which increased the urban population with the newcomers [10], who are "pulled into the city or pushed out of the countryside" [11].

The idea of centrality deals with the effect of the geographical location of a specific area in the city [12], due to the spatial concentration in the central parts of urban areas [13]. In simple words, a place is more central if it is geographically closer to other parts of the city than other places [14]. The level of centrality is affected by the proximity, accessibility, or position of the node [15]. This concept is related to the level and number of

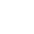

(1)


activities in a specific urban place [16]. Accessibility and the characteristics of transporta- 1 tion systems affect the centrality level [10] and the attractiveness of a specific place [17].

\subsection{The role of transportation networks in enforcing centrality}

Urban transportation moves people and goods among different places causing several effects on the city structure and land-use systems [18, 19]. The basic role of transportation is to overcome spaces and facilitate the mobility of people, goods, and information [19]. As the transportation network is one of the infrastructure networks in the city [20], its distribution controls the accessibility level and the centralization or decentralization of specific areas [21]. On the other hand, we could evaluate the efficiency of the transportation networks depending on measuring the level of centrality [22]. In this way, transportation systems have affected the spatial organization of urban areas [23]. They also have affected the urban form and function [24]. In this regard, accessibility plays a major role in the distribution and development of transportation systems [25]. People are more likely to live in places that ensure a high level of connection with their main destinations. The higher connection a place has, the more centralized it becomes and vice versa. Geographical locations and the development of transportation systems affect the accessibility level by enforcing the central positions for some areas and resulting in the peripheral locations for other places [21].

\section{Case study: Budapest city}

The chosen case study is Budapest; the capital city of Hungary and its biggest city with a population of 1.7 million. Danube river divides it into two sides; Buda and Pest which were merged in 1873 with Óbuda to form the city of Budapest [26]. The public transportation systems of Budapest are controlled by "BKK Centre for Budapest Transport". The public transportation network in Budapest consists of metros, trams, buses, trolleybuses, and suburban trains besides the regional buses and trains. This network connects Budapest city and its agglomerations [27].

\section{Methodology: measuring centrality}

This proposal presents an example of measuring centrality and analyzing the transportation network as a step for achieving this analysis in more detail after gathering the whole needed data. Regarding that, the proposed method will apply two measurements of centrality; degree centrality and closeness centrality, on the public transportation network in Budapest. In future research this will be extended to contain trains, regional buses networks, and the traffic of private cars, to have more accurate data for measuring centrality.

Measuring centrality starts with building the network by specifying the nodes and edges. In the proposed case study; each intersection between different public transportation routes is considered as a node and the line that is connected between two different nodes is considered as an edge. Building the network will be accompanied by achieving network corrections to avoid interruptions or overlapping within the network. This step is followed by measuring degree centrality which represents the number of connections of each node, and closeness centrality which represents how much a node is close to other nodes in the network. These two measurements will help in specifying the most central nodes in the network to show an example of the effect of transportation networks in enforcing or weakening the centrality of different urban areas.

\section{Results: the centrality of the public transportation network in Budapest}

The analyzed network of public transportation; which connects different urban places in Budapest city and connects Budapest city with its agglomerations, consists of 1501 nodes and 1500 edges. The analysis shows varying levels of centrality among 
different areas of the network depending on the location of the node and the number of 1 connected routes; as shown in Figure 1.

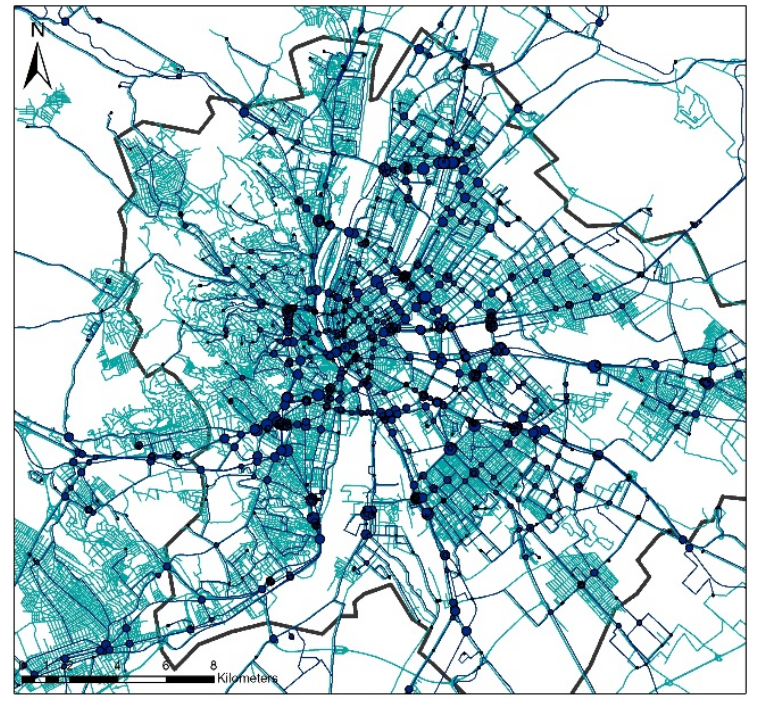

(a)

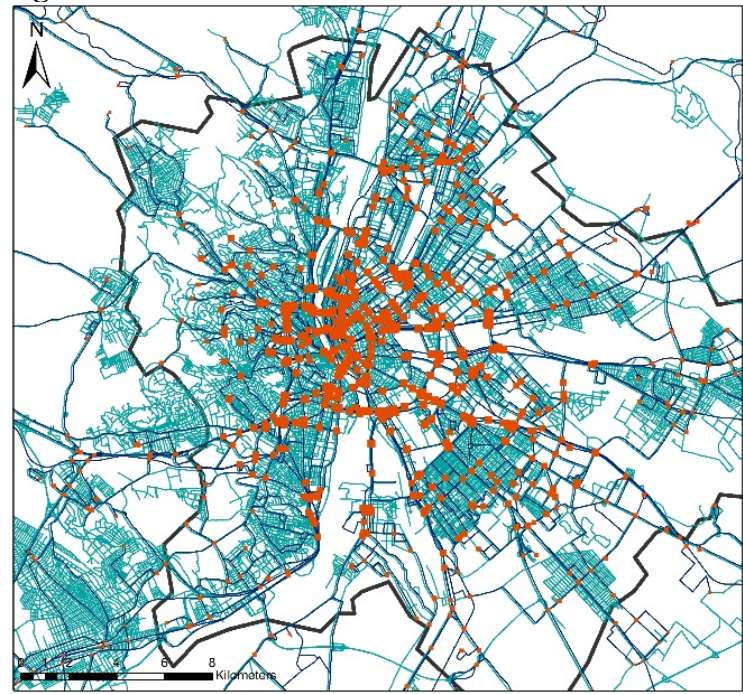

(b)

Figure 1. The centrality of the public transportation network in Budapest: (a) Degree centrality; (b) Closeness Centrality.

Both measurements; degree centrality and closeness centrality show high levels in the central districts of Budapest where the major urban activities and major centers are located. In addition to high levels in the subcenters to the north, southeast, and southwest of Budapest. On the other hand, the measurements show low levels of centrality in other parts of Budapest. This difference is related to the urban structure of Budapest city and its growth pattern. It shows unbalanced levels of centrality among different urban areas which causes many problems to the urban environment. However, dealing with transportation networks as a tool to solve centrality problems and achieve more balance between different urban areas could help in improving the city and avoiding possible problems in the future development plans.

To achieve this improvement and enhance the proposed scenarios of the city development, more detailed centrality measurements will be conducted. Centrality measurements will also include betweenness and straightness centrality. All transportation networks, the number of passengers, and the frequency of each trip will be taken into consideration. Achieving this will help in presenting a more accurate perception of the current situation and more understanding of the role of transportation systems. Understanding these issues will be useful to improve the current urban situation and build more stable plans for the city to support its development towards sustainability and build sustainable urban mobility.

Funding: This research received no external funding.

Acknowledgments: The author would like to thank Dr. Gábor Szalkai for supervising this research which is a part of a Ph.D. work, and the Center for Budapest Transport (BKK) for the useful data which they provided. The author would also like to thank Tempus Public Foundation for providing the Stipendium Hungaricum Scholarship.

Conflicts of Interest: The author declares no conflict of interest.

\section{References}

1. Kuper, A.; Kuper, J. The social science encyclopedia: (vol 1). 3rd ed.; Routledge: New York, NY, 2004. doi: 10.4324/9780203496169.

2. Maunier, R. The Definition of the City. Am J Sociol 1910, 15, 536-48.

3. Ofem, B.I. A Review of the Criteria for Defining Urban Areas in Nigeria. J Hum Ecol 2012, 37, 167-71. doi:10.1080/09709274.2012.11906461. 
4. INSEE: The National Institute of Statistics and Economic Studies. Urban area: Definition. Available online: https://www.in- 1 see.fr/en/metadonnees/definition/c2070. Accessed on 18 Aug 2021.

5. Neal, Z.P. The Connected City: How Networks are Shaping the Modern Metropolis; Routledge: New York, NY, 2012. doi: $10.4324 / 9780203101728$.

6. Gregory, D.; Johnston, R.; Pratt, G.; Watts, M.J.; Whatmore, S. The dictionary of human geography. 5th ed.; Blackwell Publishing Ltd: Hoboken, New Jersey, 2009.

7. Frey, W.H.; Zimmer, Z. Defining the City. In Handbook of Urban Studies; Paddison, R., Eds.; SAGE Publications Ltd: London, UK, 2001, pp. 14-35. doi: 10.4135/9781848608375.n2.

8. Knox, P.L. Urbanization. In International Encyclopedia of Human Geography; Kitchin, R., Thrift, N., Eds.; Elsevier, 2009 , pp. 112-8. doi: 10.1016/B978-008044910-4.01108-1.

9. Global Migration Data Portal. Urbanization and migration. Available online: https://www.migrationdataportal.org/themes/urbanisation-et-migration. Accessed on 25 Aug 2021.

10. Abdullahi, S.; Pradhan, B.; Al-sharif, A.A. Introduction to Urban Growth and Expansion. In Spatial Modeling and Assessment of Urban Form; Pradhan, B., Eds.; Springer: Serdang, Malaysia, 2017, pp. 3-15. doi: 10.1007/978-3-319-54217-1_1.

11. Dufhues, T.; Buchenrieder, G.; Sun, Z. Exploring Policy Options in Regulating Rural-Urban Migration with a Bayesian Network: A Case Study in Kazakhstan. Eur J Dev Res 2021, 33, 553-77. doi:10.1057/s41287-020-00280-1.

12. Agryzkov, T.; Tortosa, L.; Vicent, J.F.; Wilson, R. A centrality measure for urban networks based on the eigenvector centrality concept. Environ Plan B Urban Anal City Sci 2017, 46, 668-89. doi: 10.1177/2399808317724444.

13. Bunting, T.E.; Filion, P.; Priston, H. Changing patterns of residential centrality: Population and household shift in large Canadian CMAs, 1971-1996. Cah Geogr Que 2000, 44, 341-61. doi:10.7202/022925ar.

14. Li, J.; Qian, J.; Liu, Y. A Novel Analysis Method of Geographical Centrality Based on Space of Flows. ISPRS Int J Geo-Information 2017, 6, 153. doi:10.3390/ijgi6050153.

15. Strano, E.; Viana, M.; Costa, L. da. F.; Cardillo, A.; Porta, S.; Latora, V. Urban street networks, a comparative analysis of ten European cities. Environ Plan B Plan Des 2013, 40, 1071-86. doi:10.1068/b38216.

16. Cutini, V. Centrality and land use: Three case studies on the configurational hypothesis. CyberGeo Eur J Geogr 2001, 188. doi: 10.4000/cybergeo.3936.

17. Banister, D.; Lichfield, N. The Key Issues in Transport and Urban Development. In Transport and Urban Development; Banister D., Eds.; E \& FN Spon: London, UK, 1995, pp. 1-16.

18. Shaw, S-L. Transportation and Land Use. In International Encyclopedia of Human Geography; Castree, N., Crang, M., Domosh, M., Eds.; Elsevier, 2009, pp. 470-5. doi: 10.1016/B978-008044910-4.01038-5

19. Rodrigue, J-P.; Comtois, C.; Slack, B. The Geography of Transport Systems. 3rd ed.; Routledge: New York, NY, 2013. doi: $10.4324 / 9780203371183$.

20. Monclús, J. Urban Transport and Technological Urbanism. In Urban Visions: From Planning Culture to Landscape Urbanism; Medina Díez, C., Monclús, J., Eds., Spriger: Cham, Switzerland, 2017, pp. 187-96. doi: 10.1007/978-3-319-59047-9_18.

21. Gutierrez, J. Transport and Accessibility. In International Encyclopedia of Human Geography; Castree, N., Crang, M., Domosh, M., Eds.; Elsevier, 2009, pp. 410-7. doi: 10.1016/B978-008044910-4.01030-0.

22. Crucitti, P.; Latora, V.; Porta, S. Centrality in networks of urban streets. Chaos 2006, 16, 1-9. doi:10.1063/1.2150162.

23. Wegener, M. Accessibility and Development Impacts. In Transport and Urban Development; Banister D., Eds.; E \& FN Spon: London, UK, 1995, pp. 157-61.

24. Herbert, D.; Thomas, C. Cities In Space: City as Place. 3rd ed.; David Fulton Publishers: London, UK, 1997. doi: 10.4324/9781315067766.

25. Lecompte, M.C; Bocarejo, S. JP. Transport systems and their impact con gender equity. Transportation Research Procedia 2017, 25, 4245-57. doi: 10.1016/j.trpro.2017.05.230

26. Tóth-Ronkay, M., Bajor, Z., Bárány, A., Földvári, G., Görföl, T., Halpern, B., et al. Budapest. In Vertebrates and Invertebrates of European Cities:Selected Non-Avian Fauna; Springer: New York, NY, 2015. pp. 27-73. doi: 10.1007/978-1-4939-1698-6_2\%0A.

27. Budapesti Közlekedési Központ. Available online: https://bkk.hu/en/. Accessed on 8 Dec 2021. 